\title{
Acetylcholine in the Crayfish Optic Lobe: Concentration Profile and Cellular Localization
}

\author{
Lolin T. Wang-Bennett, ${ }^{a}$ Cindy Pfeiffer, James Arnold, and Raymon M. Glantz \\ Department of Biology, Rice University, Houston, Texas 77251
}

\begin{abstract}
The crayfish optic lobe contains high levels of acetylcholine (ACh) and choline as measured with a chemiluminescent assay in small fragments of optic lobe tissue. The highest concentrations were found in the medulla externa and medulla interna (second and third optic neuromeres), which have ACh concentrations of $270 \mathrm{pmol} / \mathrm{mg}$ tissue. This concentration is about 16 times that measured in the photoreceptors and lamina ganglionaris (the first optic neuromere).

Immunocytochemistry (based upon antisera to cholineglutaryl-BSA) revealed low levels of ACh-like reactivity in the lamina ganglionaris associated with the terminal arbors of centrifugal and/or tangential neurons. The most intense ACh-like reactivity was observed in monopolar neurons of the medulla externa and medulla interna. One monopolar neuron/medullary column (or about 2500 neurons/medullary neuropile) exhibited reactivity and an estimated cytoplasmic concentration of $8.1 \mathrm{~mm}$.
\end{abstract}

The neuronal ensembles of arthropod optic ganglia provide striking examples of a precise neuronal architecture organized for the parallel processing of visual information. The basic plan consists of a retinotopic array of columnar projection neurons serially connected in 4 optic ganglia. In each ganglion, the transverse dendrites of multicolumnar neurons intersect the columnar projection in a 3-dimensional grid. In several insects (particularly in diptera) and crustaceans, the synaptic connections between a number of the identified cell classes have been described morphologically (Strausfeld and Nassel, 1980). More rccently, the physiological charactcristics of the neurons in the first 2 optic neuromeres in crayfish have been documented (Kirk, 1982; Waldrop and Glantz, 1985a, b; Wang-Bennett and Glantz, 1987a, b).

The above features make the optic lobe an attractive subject for the cytochemical analysis of neurotransmitters. The earliest studies used a variety of methods such as formaldehyde-induced nuorescence for catecholamines (Elofsson and Klemm, 1972; Elofsson et al., 1977), alpha-bungarotoxin binding for ACh receptors (Schmidt-Nielsen et al., 1977; Maxwell and Hildebrand, 1981 ) and the incorporation of radioactive precursors (CamposOrtega, 1974; Maxwell and Hildebrand, 1981; Elias and Evans,

\footnotetext{
Received June 15, 1988; revised Oct. 21, 1988; accepted Oct. 24, 1988.

This work was supported by Grant BNS-8711141 from the National Science Foundation.

Correspondence should be addressed to Raymon M. Glantz, Department of Biology, Rice University, P.O. Box 1892, Houston, TX 77251.

a Present address: Department of Otorhinolaryngology and Communicative Sciences, Baylor College of Medicine, One Baylor Plaza, NS A-513, Houston, TX 77030 .

Copyright (C) 1989 Society for Neuroscience $0270-6474 / 89 / 061864-08 \$ 02.00 / 0$
}

1984). Quantitative assays have been based upon neurotransmitter extraction from optic lobe fragments and analysis by electrophoresis and high-performance liquid chromatography (Maxwell et al., 1978; Maxwell and Hildebrand, 1981; Elofsson et al., 1982; Elias and Evans, 1983; Garcia and Arechiga, 1986). These studies indicate that the optic lobe contains significant quantities of $\mathrm{ACh}, \mathrm{GABA}$, octopamine, dopamine, serotonin, and histamine.

More recently, immunocytochemistry has been used to localize a number of neurotransmitters and neuropeptides in the optic lobes of several species. These studies have mapped the distribution of enkephalin-like and substance P-like peptides (Mancillas et al., 1981); GABA (Datum et al., 1986; Meyer et al., 1986; Homberg et al., 1987), serotonin (Beltz and Kravitz, 1983; Elofsson, 1983; Nassel et al., 1985), the peptide proctolin (Siwicki and Bishop, 1986), dopamine (Vieillemaringe et al., 1984), choline acetyltransferase (Buchner et al., 1986; Gorczyca and Hall, 1987), and a crustacean peptide hormone (Schueler et al., 1986).

Several lines of evidence indicate that there is a major cholinergic pathway in the optic lobes of flies and moths (SchmidtNielsen et al., 1977; Maxwell et al., 1978; Maxwell and Hildebrand, 1981; Gorczyca and Hall, 1987). In the moth, ACh is the most prevalent transmitter in the optic lobe. In Drosophila melanogaster antibodies to choline acetyltransferase stain putative monopolar neurons and centrifugal neurons in the lamina and columnar neurons in the 3 more proximal optic neuromeres (Buchner et al., 1986; Gorczyca and Hall, 1987). In the present study, ACh and choline were assayed in the crayfish optic lobe, and the highest concentrations of both substances were found in the medulla externa and the medulla interna (second and third optic neuromeres). Additionally, we have examined the optic lobe with antisera developed for the immunocytochemical detection of ACh (Geffard et al., 1985). We found ACh-like immunoreactivity in a centrifugal neuron of the lamina and a subset of the columnar visual interneurons (transmedullary neurons) of the second and third optic neuromeres. Some of the immunocytochemical results were presented previously in abstract form (Wang-Bennett and Glantz, 1986).

\section{Materials and Methods}

Neurochemical analysis. The concentration of choline and ACh in the optic lobe, brain, and abdominal ganglia of adult craytish were measured by the chemiluminescent method of Israel and Lesbats $(1981,1987)$. The procedure is based upon the conversion of ACh to choline by acetylcholinesterase (AChE) and the conversion of choline to betain and hydrogen peroxide by choline oxidase (Ikuta et al., 1977). Two mol of $\mathrm{H}_{2} \mathrm{O}_{2}$ are generated per mol of choline oxidized. The $\mathrm{H}_{2} \mathrm{O}_{2}$ concentration is measured in a peroxidase-luminol system by the oxidation and light emission of luminol. A schematic of the apparatus used in this study 


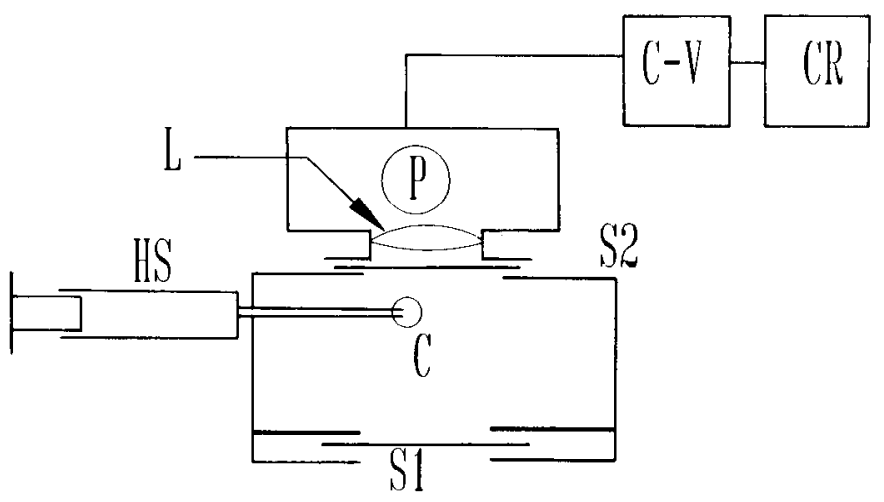

Figure 1. Schematic drawing of apparatus for chemiluminescence measurements. The chemical reaction takes place in a glass vial in the reaction chamber $(C)$ and is initiated by the delivery of reactants from a Hamilton syringe (HS). Iight produced by the reaction is focused by collecting lens $(L)$ to the cathode of a photomultiplier tube $(P)$. The current of the photomultiplier is converted to a voltage by a currentto-voltage converter $(C-I)$ and recorded with a Gould chart recorder $(C R)$. Access to the reaction chamber and the photomultiplier is restricted by 2 shutters, $S 1$ and $S 2$, respectively.

is shown in Figure 1. The light emitted by luminol was focused with a collector lens (L) and measured from the current of a photomultiplier tube (P; Oriel 77340). The cathodal photomultiplier current was detected by a current-to-voltage converter (C-V) and recorded on a Gould chart recorder (CR). With a modest amount of effort, this system can detect $2.5 \mathrm{pmol} \mathrm{ACh}$ in a $50 \mu \mathrm{l}$ volume $\left(5 \times 10^{-8} \mathrm{M}\right)$ at a $5: 1$ signal-tonoise ratio. The measuring device also requires 2 shutters (S1, S2). Opening one shutter, S1, provides access to the reaction chamber (C), while the photomultiplier is shielded by the second shutter, S2. During measurement, the chamber was sealed by closing $\mathrm{S} 1$ and the photomultiplier was exposed to the reaction vessel by opening S2. A $250 \mu \mathrm{l}$ Hamilton syringe (HS) with a fixed hypodermic needle was used to deliver reactants into a glass vial within the sealed reaction chamber.

Several stock solutions were prepared prior to our measurements. Choline oxidase (Boehringer Mannheim) at $50 \mathrm{U} / \mathrm{ml}$ is obtained in a solution of $4 \mathrm{M} \mathrm{NaCl}$ and $10 \mathrm{~mm}$ EDTA. It is stable at $4^{\circ} \mathrm{C}$ for about 6 months. Luminol (Sigma) is dissolved in a few drops of $\mathrm{NaOH}$, and a $1.0 \mathrm{~mm}$ concentration was prepared daily in a $0.2 \mathrm{~m}$ Tris- $\mathrm{HCl}$ buffer,
$\mathrm{pH}$ 8.6. HRP type II (Sigma) was prepared as a solution of 330 purpurogallin $\mathrm{U} / \mathrm{ml}$ in distilled water. Small volumes were stored at below $-40^{\circ} \mathrm{C}$. AChE from Electrophorus electricus (Boehringer Mannheim) was dissolved in water $(1000 \mathrm{U} / \mathrm{ml})$ and desalted in a $5 \mathrm{ml}$ Sephadex $\mathrm{G} 50$ column and recovered at $330 \mathrm{U} / \mathrm{ml}$. The esterase was either kept at $4^{\circ} \mathrm{C}$ to be used in a day or so, or separated into $100 \mu \mathrm{l}$ aliquots and stored at below $-40^{\circ} \mathrm{C}$. An alkaline buffer solution, $\mathrm{pH} 8.6$, contained either $200 \mathrm{~mm}$ sodium phosphate or $120 \mathrm{~mm}$ sodium chloride and 50 mM Tris- $\mathrm{HCl}$.

Two milliliters of the reaction solution was prepared from $1.7 \mathrm{ml}$ of alkaline buffer and $100 \mu \mathrm{l}$ each of the luminol, HRP, and choline oxidase stock solutions.

Measurements were made with $200 \mu \mathrm{l}$ volumes of the reaction solution in a glass vial. The reaction to measure the choline concentration was initiated by the rapid injection of a $50 \mu \mathrm{l}$ sample via the Hamilton syringe into the enclosed vial. In our initial experiments, high choline readings in several tissues led us to suspect the presence of peroxides or other contaminants in the lissue extracts that were confounding the choline measurements. To control for endogenous peroxides, the choline oxidase was withheld from the initial reaction mixture, and the tissue extracts were allowed to equilibrate in the HRP-luminol mixture. Then, the choline measurement was initiated by the addition of choline oxidase. As expected, this procedure substantially reduced the amplitude of the choline response in most tissues but had no effect on the ACh measurement. The ACh measurements in tissue extracts were initiated after the complete oxidation of the choline by the addition of 3 units of $\mathrm{AChE}$ to the vial.

Figure 2 (upper left) shows the response to 5 and $50 \mathrm{pmol} \mathrm{ACh}$ standards. A comparison of the 2 voltage traces clearly indicates that the system output is nonlinearly related to the $\mathrm{ACh}$ concentration. Thus, a 10 -fold increase in $\mathrm{ACh}$ concentration produces a 2.4-fold increase in peak voltage and in the time integral of the signal. Figure 2 (right) is a calibration curve for choline (solid line) and ACh (broken line) based upon 8 repetitions of each indicated concentration. The instrument was calibrated over the range of $5.0-500 \mathrm{pmol}$ in $50 \mu \mathrm{l}$ volumes for each preparation and for each variant of our procedures.

Extraction of $A C h$ and choline. Nerve tissue from the optic lobe, brain, and abdominal ganglia was rapidly dissected, excised, and placed in icecold 5\% trichloracetic acid (TCA; wt/vol). The TCA served the dual purpose of rapidly denaturing the cholinesterase while extracting the choline and $\mathrm{ACh}$ from the tissues. The optic neuromeres (see Fig. 4 for relative locations) were separated into 3 tissue blocks with a sharp microdissecting scalpel. One block contained the photoreceptors and the lamina ganglionaris (L), a second contained and medulla externa (ME) and medulla interna (MI), and the third contained the medulla terminalis (MT). Samples of brain, abdominal ganglia, and abdominal
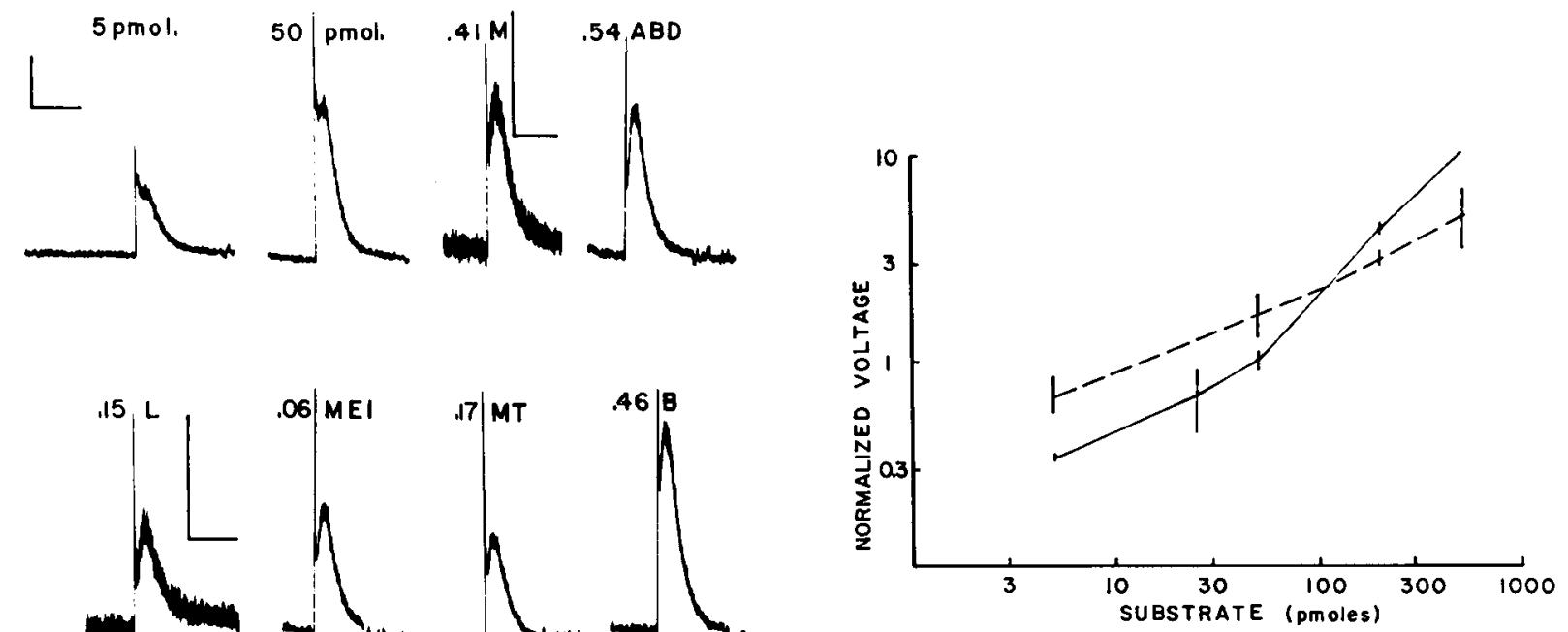

Figure 2. Responses of the measurement system to ACh standards of 5.0 and $50 \mathrm{pmol}$ and to $50 \mu \mathrm{l}$ samples of tissue extract from abdominal flexor muscle $(M)$, abdominal ganglia $(A B D)$, photoreceptors and lamina ganglionaris $(L)$, medulla externa and interna $(M E I)$, medulla terminalis $(M T)$, and brain $(B)$. Preceding each label is the amount of tissue extracted (in $\mathrm{mg}$ ) for the $50 \mu \mathrm{l}$ sample. Calibration bars ( $u p p e r$ left) indicate 500 $\mathrm{mV}$ and $40 \mathrm{sec}$. This scale applies to all panels but the muscle $(M)$ and lamina $(L)$ measurements, where a higher voltage gain is indicated. The graph to the right contains calibration curves for choline (solid lines) and ACh (broken lines). The vertical bars indicate \pm SEM. Each point is the average of 8 determinations. 

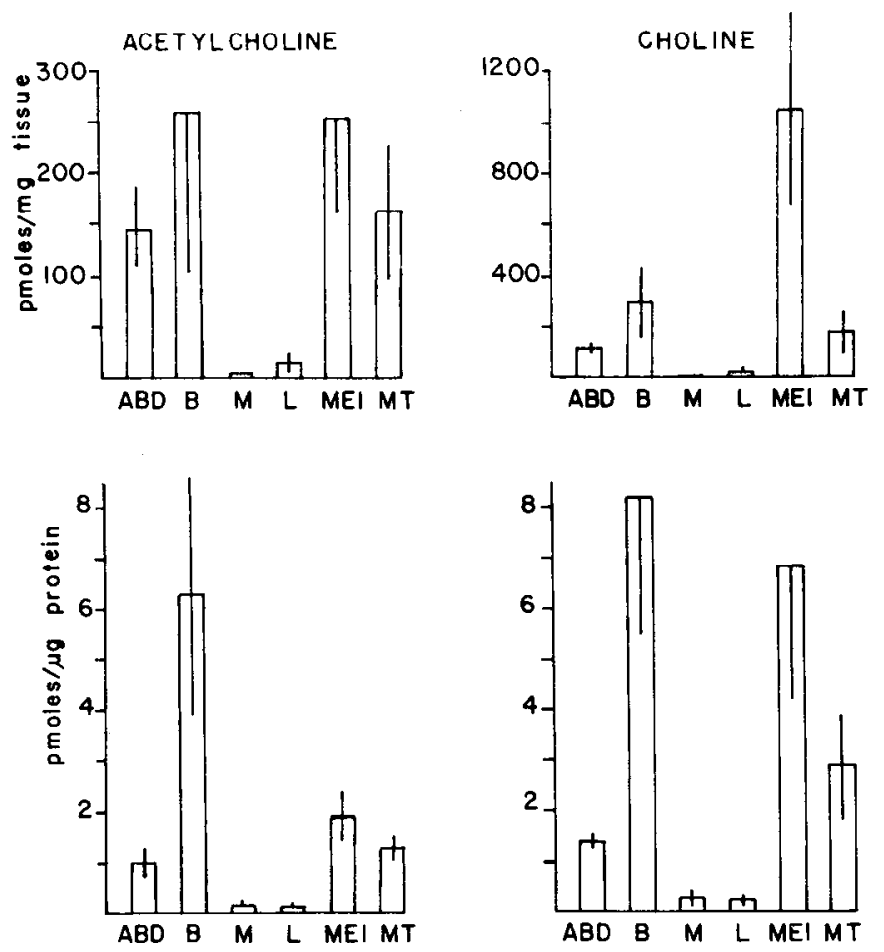

Figure 3. Distribution of $\mathrm{ACh}$ and choline in the optic lobe (L, MEI, and $M T$ ), brain $(B)$, abdominal ganglia $(A B D)$, and abdominal muscle $(M)$. The results are averages based upon separate determinations in 4 animals. Error bars indicate SEM. The 2 upper graphs indicate ACh and choline content per mg wet tissue weight. The lower graphs indicate $\mathrm{ACh}$ and choline/ $\mu \mathrm{g}$ protein.

flexor muscle were also prepared. Each tissue block (1-3 mg for the eye samples) was weighed in $200 \mu \mathrm{l} \mathrm{TCA}$. The tissue was minced manually, agitated in the cold TCA for $1 \mathrm{hr}$, and centrifuged. The pellet containing the precipitated denatured protein was frozen for subsequent analysis by a modified Lowry method (Ohnishi and Barr, 1978). To remove the TCA, the supernatant was mixed with $2-3 \mathrm{ml}$ of water-saturated ether and vigorously shaken. The ether phase was removed with a pipette and the process was repeated 6 times. The residual ether was evaporated with an air stream.

To minimize the blocking action of endogenous reducing agents on our assay, the tissue extracts were oxidized with a final concentration of $0.05 \%$ potassium iodate (wt/vol). Blank samples subjected to TCA, ether, and potassium iodate produced no false-positive responses in our assay.

Immunocytochemistry. Adult crayfish, Procambarus clarkii, were cooled for $2 \mathrm{hr}$ at $4^{\circ} \mathrm{C}$ in oxygenated saline. The cuticle of the eyestalk was removed in the presence of the primary fixative $(0.1 \mathrm{M}$ cacodylate buffer, $\mathrm{pH} 11,1 \mathrm{~m}$ allyl alcohol, $12 \%$ formalin, and $1 \%$ sodium metabisulfite). The optic lobe was excised and desheathed in the secondary fixative, Bouin-sublimate solution (saturated picric acid, 12\% formalin, $1 \%$ sodium metabisulfite, and saturated mercuric chloride) and fixed for $36 \mathrm{hr}$ at $4^{\circ} \mathrm{C}$ in the dark. The optic lobe was then washed for $8 \mathrm{hr}$ in $0.1 \mathrm{M}$ Tris- $\mathrm{HCl}$ buffer and immersed in normal goat serum (NGS) for $4 \mathrm{hr}$ to reduce nonspecific binding by the secondary antibody.

Two primary antisera (one from Chemicon and the second a gift from T. Kingan, Tucson), rabbit anti-choline-glutaryl-BSA, were diluted 1: 50 in Tris buffer. The whole optic lobe was incubated with the antiserum overnight at $4^{\circ} \mathrm{C}$. The secondary antiserum was a goat anti-rabbit IgG conjugated to either FITC or peroxidase (Boehringer Mannheim). The secondary antiserum was diluted 1:30 in phosphate buffer containing $10 \%$ NGS and $0.3 \%$ Triton X-100. Both types of secondary antiserum were applied to the intact optic lobe. After a $4 \mathrm{hr}$ wash, the tissue was agitated in the secondary antiserum overnight at $4^{\circ} \mathrm{C}$.

Subsequent histological processing was standard. The peroxidase was reacted with diaminobenzidine and $\mathrm{H}_{2} \mathrm{O}_{2}$. The tissue was dehydrated, embedded in paraffin, and sectioned at $15 \mu \mathrm{m}$. The sections were pho- tographed in a compound microscope with Ektachrome slide film. The tissue containing the FITC conjugates was also dehydrated, paraffinembedded, and sectioned at $15 \mu \mathrm{m}$. The sectioned material was then viewed and photographed under incident fluorescence. Because the stained processes typically consist of fine neurites $(<3 \mu \mathrm{m}$ diameter) that occupy only a modest portion of the optic lobe, the photomicrography presentcd a scrious challenge. The fluorescent material in particular required extremely long exposures to capture the images and some overexposure to print them. Thus, the quality of these photomicrographs provides only a rough approximation of the original microscopic image.

Preabsorption studies were carried out to test for nonspecific reactivity in the primary antisera. The diluted antisera were incubated with the immunogen $\left(10^{-3} \mathrm{M}\right.$ choline-glutaryl-BSA, a gift from M.-L. Sovan and M. Geffard) at $4^{\circ} \mathrm{C}$ for $20 \mathrm{hr}$. Preabsorption totally suppressed the reactivity of the antisera.

Approximately 20 crayfish optic lobes were used to develop the fixation, incubation, and staining procedures. Once established, these procedures were applied to an additional 16 preparations. The principal result, reactivity in the axons of the medulla externa and interna, was obtained in 14 of the 16 eyes examined. The immunoreactivity of other structures was morc variable. Positive reactions in the lamina ganglionaris were observed in about half of the optic lobes. The Chemicon antisera provided positive results at a 1:50 dilution. The antibody obtained from $T$. Kingan failed to elicit reactivity at 1:50 dilution but produced unambiguous results at a 1:30 dilution. Except for the difference in absolute sensitivity, the 2 antisera produced qualitatively similar results. All of the results presented, including all of the controls and tests in the crayfish brain (see below), were obtained with a single lot of Chemicon antisera and antisera from T. Kingan. A second lot of Chemicon antisera was entirely unreactive.

The reactivity of the antisera was assessed in several locations of the brain known to contain cholinergic primary afferents (Barker et al., 1972). ACh-like reactivity was observed in the primary afferent axons of the antennal and antennulary nerves and the most intense reactivity was observed in the primary afferent terminals of the sensory neuropiles (Wang-Bennett et al., 1988).

\section{Results}

\section{Choline and $A C h$ in the optic lobe}

Figure 2 is a sample of photomultiplier recordings during $\mathrm{ACh}$ assays in abdominal flexor muscle (M), abdominal ganglia (ABD), the photoreceptors and lamina (L), the medulla externa and interna (MEI), the medulla terminalis (MT), and the brain (B). To the left of the label in each panel of Figure 2 is the amount of tissue extracted (in milligrams) for the $50 \mu \mathrm{l}$ assay sample. Each measurement was repeated 3 times in each tissue, and the mean concentrations were converted to $\mathrm{pmol} / \mathrm{mg}$ tissue. The averaged results of 4 preparations are plotted in the upper 2 histograms of Figure 3.

The ACh concentration (per mg wet tissue) in the combined ME and MI is similar to that in the brain and about twice that in the abdominal ganglia (1-5). Somewhat different ratios are obtained, however, when the ACh content is scaled by tissue protein (Fig. 3, lower histograms). The difference is due to the presence of a large vascular space (sinus) in the brain that adds much to the brain wet weight but little protein. Our estimate of the ACh content of the abdominal ganglia is comparable to similar measurements in lobster abdominal ganglia (Hildebrand et al., 1974) based on completely different techniques. For the optic neuromeres, the ratios of $\mathrm{ACh}$ content per mg tissue or $\mu \mathrm{g}$ protein is essentially the same; i.e., $\mathrm{ACh}$ in the medulla externa-interna:medulla terminalis:lamina-photoreceptors is 1 : 0.61:0.06. An unusual feature of the optic lobe measurements is the relatively high concentration of choline in the medullary neuropiles. The ME-MI contain about 3.5 times as much choline as $\mathrm{ACh}$. In other neuropiles the choline: $\mathrm{ACh}$ ratio varies from $1: 1$ to 2:1. Although the absolute magnitudes of $\mathrm{ACh}$ and choline varied somewhat from one animal to another, the relative 

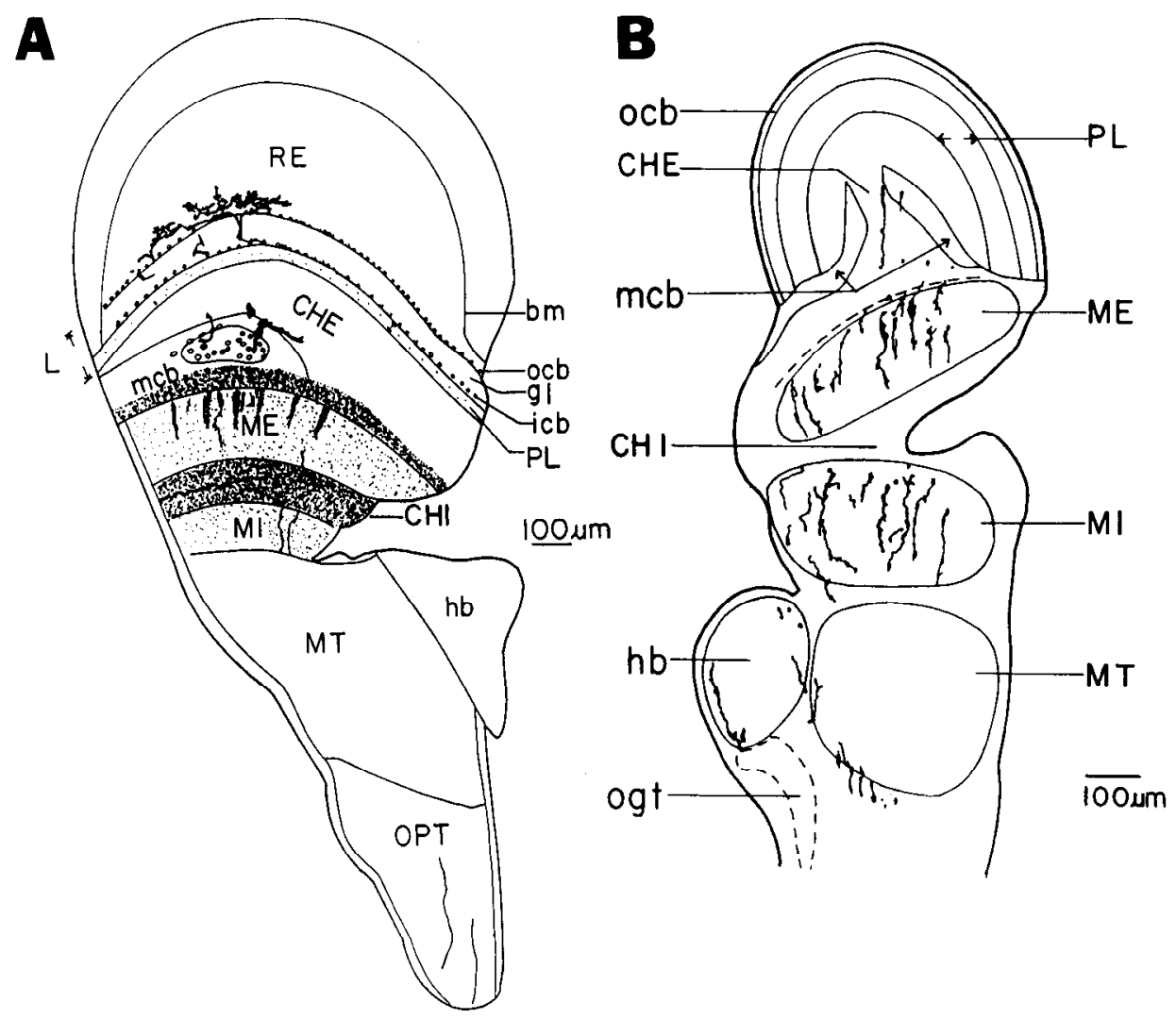

Figure 4. ACh-like immunoreactivity in the crayfish optic lobe. $A$, Reconstruction of a sagitally sectioned optic lobe with immunoreactive neurons in the lamina $(L)$, medullary cell body area $(m c b)$, the medulla externa $(M E)$, and medulla interna $(M I)$. Intense but diffuse reactivity is revealed in the rind of somata at the distal edge of the medulla externa and in the internal chiasm $(C H I)$. Right side is dorsal. $B$, Reconstruction of a horizontally sectioned optic lobe immune reactive neurons in $\mathrm{ME}$, MI, and the proximal medulla terminalis $(M T)$. Right side is the lateral optic lobe. Each drawing is a composite from several serial sections. Abbreviations: $R E$, retinular cell axons; $b m$, basement membrane; $o c b$, outer cell body layer of the lamina; $g l$, glial layer of lamina; $i c b$, inner cell body layer of lamina; $P L$, lamina plexiform layer; $C H E$, external chiasm; $h b$, hemiellipsoid body; $O P T$, optic peduncle; ogt, olfactory-glomerular tract.

amounts in the 3 optic lobe samples was highly reproducible. The same is true for the high choline:ACh ratios in the optic medullary neuropiles. The abdominal fast flexor muscles were included in the assay to probe the measuring system's response to tissue known to contain very low levels of ACh $(0-0.12 \mathrm{pmol}$ $\mu \mathrm{g}$ protein, Hildebrand et al., 1974). It is notable that our estimate of muscle $\mathrm{ACh}$ content, $0.17 \mathrm{pmol} / \mu \mathrm{g}$ protein, is very similar to the ACh content of the lamina ganglionaris, 0.13 $\mathrm{pmol} / \mu \mathrm{g}$ protein.

\section{Immunocvtochemical detection of $A C h$-like reactivity}

Figure 4 indicates the distribution of ACh-like immunoreactivity in the crayfish optic lobe. No reactivity was ever observed in the axons of the retinular cells (RE). In the lamina ganglionaris (L), the staining intensity is quite modest, but the pattern of reactivity is distinct and suggestive of the terminal arborization of tangential cells and/or centrifugal neurons (C2). Figure 5 (inset) and Figure 6 reveal the pattern of lamina reactivity as observed with peroxidase and FITC conjugates, respectively. Tangential cells originate proximal to the lamina in the medullary cell body area (Wang-Bennett and Glantz, 1987b) and the centrifugal cells arise on the proximal side of the second optic ganglion, the medulla externa (ME) (Strausfeld and Nassel, 1980). The tracings on the top of Figure $4 A$ and the processes in Figures 5 and 6 (all from different preparations) indicate a terminal arbor several columns wide and distal to the lamina plexiform. Just proximal to the lamina is the external chiasm (CHE) and the medullary cell body area (mcb) (Fig. 4). A minority of somata in the cell body area (typically 5-15) exhibit ACh-like reactivity (Fig. 6, MCB). The reactive somata are similar in location and size to the cell bodies of tangential cells (15-25 $\mu \mathrm{m}$ diameter) and T-neurons (about $10 \mu \mathrm{m}$ diameter) (Strausfeld and Nassel, 1980; Wang-Bennett and Glantz, 1987b).

The most reactive sites in the optic lobe are the medulla externa (ME) and the medulla interna (MI). The putative cholinergic elements in both neuromeres are transmedullary monopolar cells (Fig. 4). The proximal neurites of the transmedullary neurons are 2-3 $\mu \mathrm{m}$ diameter (Figs. 5 and 6, ME and MI) and course parallel to the long axis of the eyestalk. Previous studies (Strausfeld and Nassel, 1980) indicate that transmedullary neurons give rise to dense but narrow field $(10-15 \mu \mathrm{m})$ dendritic projections. The extremely fine dendrites illustrated in Figure $4 A$ did not reproduce in the photomicrographs, but the origins of these dendrites can be seen as protuberances on the monopolar cell axons in Figure 6, ME, MI. The distal edges of the medullae are surrounded by a rind of cell bodies. A few of these monopolar cell bodies exhibit ACh-like reactivity (Figs. 5, 6). The reactive neurites exhibit an approximately periodic spacing (Fig. 5, ME and MI), with intcrvals of 12-18 $\mu \mathrm{m}$. This spacing is approximately equal to the width of the medullary columns and suggests the presence of one putative cholinergic neuron per medullary column or about 2500 cholinergic neurons per medullary neuropile.

The fourth optic ganglion is the medulla terminalis (MT), which is adjacent to the hemiellipsoid body (hb; Fig. 4). Reactivity in these neuropiles is concentrated in the hemiellipsoid body and at the edges of the medulla terminalis (Figs. $4 B ; 5$, inset $\mathrm{MT}$ ).

\section{Discussion}

Our results indicate that crayfish photoreceptors and lamina ganglionaris contain only minute amounts of choline and $\mathrm{ACh}$. 

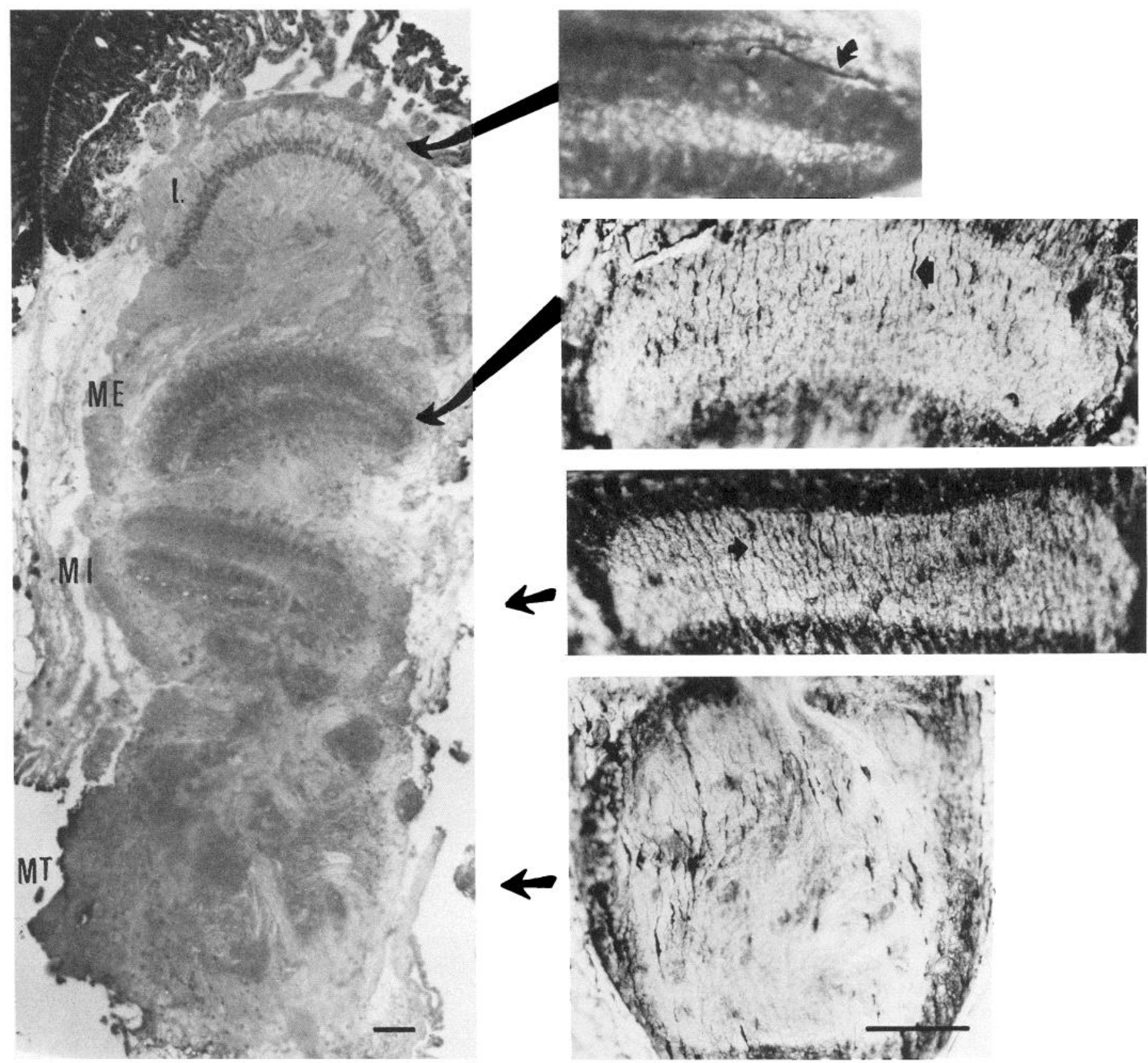

Figure 5. Distribution of ACh-like reactivity in the crayfish optic lobe as revealed by antisera conjugated to HRP. At left is an unstained lowpower micrograph of the optic lobe which indicates the locations and orientations of the optic neuromeres, lamina ganglionaris $(L)$, and medulla externa, interna, and terminalis ( $M E, M I$, and $M T$, respectively). Adjacent to each neuromere is a higher-power inset which indicates the immunoreactive elements in that neuromere. The lamina inset contains the reactive tangential process (arrow) of a tangential or centrifugal neuron. The medulla externa and interna contain reactive axons of transmedullary neurons (arrows) and the medulla terminalis contains reactive axons of unidentified neurons.

This inference is derived from our chemiluminescence measurements and is consistent with the immunocytochemistry. The ACh content of the medulla externa and interna is about $1.9 \mathrm{pmol} / \mu \mathrm{g}$ protein, which is second only to the brain and substantially greater than the level in any other structure we examined. The ACh concentration profile of the crayfish optic lobe is qualitatively similar to the distribution of choline acetyltransferase in dipteran optic lobe (Buchner et al., 1986; Gorczyca and Hall, 1987). In both organisms, cholinergic function is weak or absent in the photoreceptors and lamina neurons and strongly represented in the more central optic neuromeres. In the moth (Maxwell and Hildebrand, 1981), ACh is found in the lamina and medulla but not in the photoreceptors.

Some of the results in Figure 3 can be compared with the ACh content of other invertebrate ganglia (McCaman, 1984). In Aplysia, the ACh concentrations in the several ganglia vary from 0.3 to $0.6 \mathrm{pmol} / \mu \mathrm{g}$ protein. This is $30-60 \%$ of the value in crayfish abdominal ganglia and about $10 \%$ of the value in crayfish brain. The ACh content of the brain is somewhat less than the value reported for octopus optic lobe $(7.8 \mathrm{pmol} / \mu \mathrm{g}$ protein) and similar to the concentration in antennular hair cells in lobster (Hildebrand et al., 1974). 

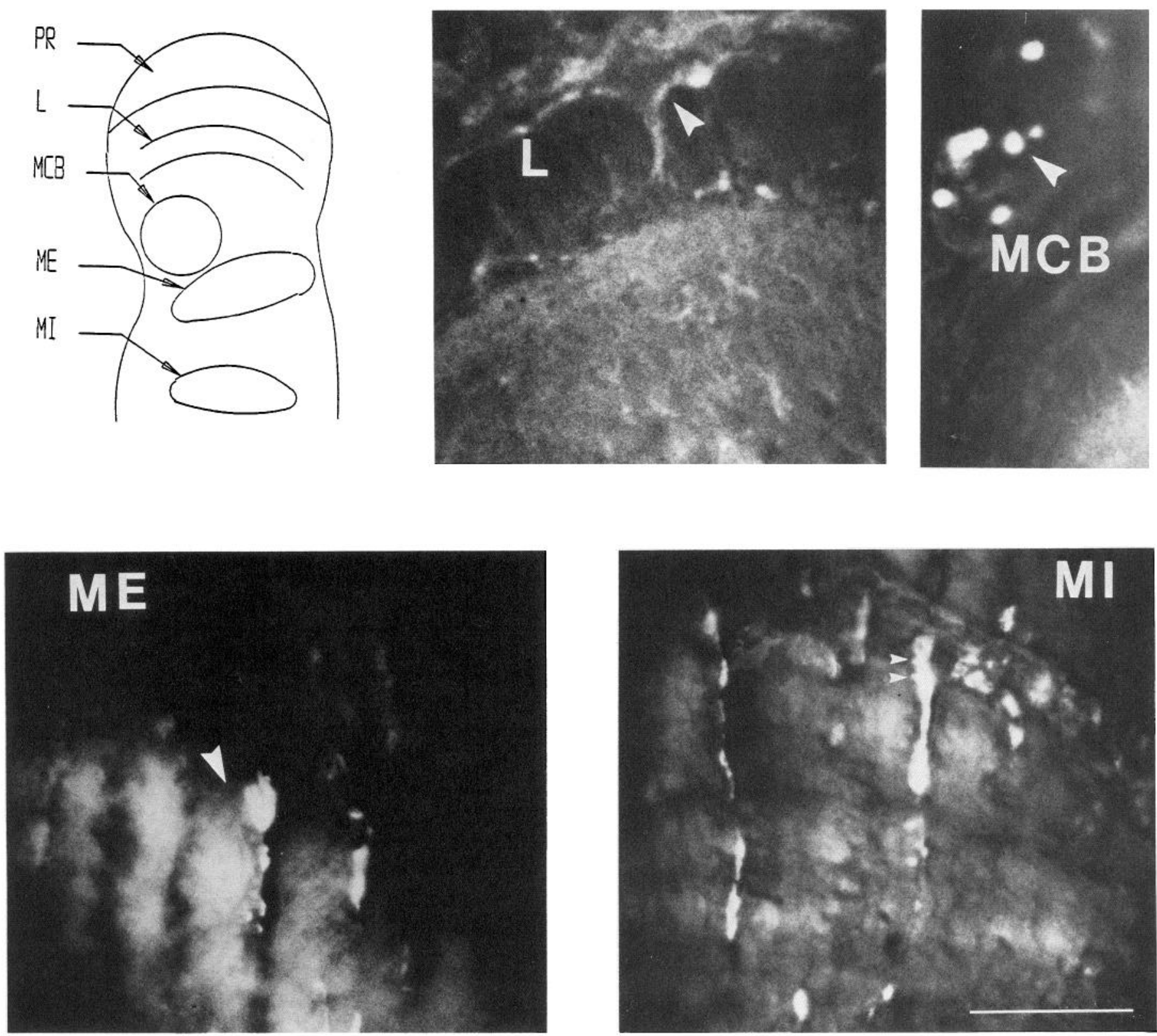

Figure 6. Distribution of ACh-like reactivity in the crayfish optic lobe as revealed by FITC conjugated antisera. Inset (upper left) is a schematic of the major optic lobe structures: $P R$, photoreceptors; $L$, lamina ganglionaris; $M C B$, medullary cell body area; $M E$, medulla externa; and $M I$, medulla interna. The photomicrographs indicate a reactive tangential cell $($ arrow $)$ in the lamina $(L)$ somata in the medullary cell body area $(M C B)$, and monopolar cell processes in the medulla externa $(M E)$ and interna $(M I)$.

As noted above, the $\mathrm{ACh}$ and choline content of the abdominal ganglia, about $150 \mathrm{pmol} / \mathrm{mg}$ tissue, is similar to that in lobster (Hildebrand et al., 1974). In the lobster abdominal ganglia (and numerous other arthropods), there is good evidence that much of the $\mathrm{ACh}$ is associated with primary afferents, where $\mathrm{ACh}$ functions as a neurotransmitter. Similar findings are documented for the choline acetyltransferase activity in the brains and afferent roots of lobsters (Barker et al., 1972; Hildebrand et al., 1974) and the ACh-like immunoreactivity of crayfish brain (Wang-Bennett et al., 1988). The presence of 6 bilateral primary sensory neuropiles in the brain is presumably the basis of its high ACh concentration. In crayfish brain, however, a number of interneurons were also found to be cholinergic as revealed by immunocytochemistry.
The structure and location of the immunoreactive cells in the medulla externa and interna indicate that they are transmedullary monopolar neurons, i.e., a subset of the columnar neurons of the second and third optic neuromeres (Strausfeld and Nassel, 1980). The identification is based upon the location of the cell bodies at the distal edge of the medulla, the orientation of the axons parallel to the long axis of the eyestalk, and the relatively narrow field (10-15 $\mu \mathrm{m})$ of processes in the medullary neuropile. Within the medulla, favorable sections exhibit a periodic staining pattern with adjacent reactive axons separated by $12-18 \mu \mathrm{m}$. This is precisely the pattern to be expected if each medullary column contains a single cholinergic monopolar neuron. This same pattern is repeated in the medulla interna.

An essential feature of the arthropod optic lobe is the reti- 
notopic columnar projection system (Strausfeld and Nassel, 1980). In crayfish, 5 lamina monopolar ganglion cells constitute the principal second-order elements of a lamina cartridge. The monopolar cells of one cartridge receive photoreceptor signals from one ommatidium (there is one lamina cartridge/ommatidium), and they project their axons retinotopically via a horizontal decussation to a column of transmedullary monopolar neurons in the second optic ganglion, the medulla externa. A working hypothesis is that the monopolar cells within a single column provide selective information channels, e.g., for orthogonal e-vectors of polarized light and stimulus intensity (Nassel and Waterman, 1977; Wang-Bennett and Glantz, 1987a). It is also inferred from morphological data that the retinotopic columns form a homogeneous spatial array in which homologous elements in every column make essentially the same synaptic connections and carry out the same functions. Functional studies (Kirk et al., 1982; Waldrop and Glantz, 1985b) indicate that this general concept is also valid in the medullary neuropile. Thus, it is not unlikely that the cholinergic monopolar cells constitute a homogeneous neuronal class and that ACh conveys the same visual signal across the entire retinotopic array. Our finding that there is one cholinergic monopolar cell/medullary column (and thus 5 noncholinergic monopolar cells) suggests the possibility that different parallel information channels may contain different neurotransmitters.

In the medulla externa, the dendrites of the multicolumnar neurons (sustaining fibers, dimming fibers, tangential cells, and medullary amacrine cells) intersect the medullary columnar projection (Kirk et al., 1982; Waldrop and Glantz, 1985a,b; WangBennett and Glantz, 1987b), and each cell class presumably receives the same type of functional input at each dendritic location (Kirk et al., 1983). These muticolumnar neurons are possible postsynaptic elements of cholinergic synapses in the medulla externa.

If the ACh concentration measurements and the immunocytochemistry are taken together, one can estimate the concentration of ACh in the medullary columnar neurons. To simplify matters, it is assumed that all of the ACh is contained in 2500 monopolar cells in each medullary neuropile. The approximate dimensions of the monopolar ncuron arc as follows: soma diameter, $20 \mu \mathrm{m}$; axon diameter, $2.5 \mu \mathrm{m}$; axon length, $500 \mu \mathrm{m}$. The combined volume of the 5000 such neurons is approximately $3.3 \times 10^{7} \mu \mathrm{m}^{3}$. If this volume contains all of the ACh measured in this tissue, $270 \mathrm{pmol}$, and the ACh is homogeneously distributed in the cell, then the concentration of ACh in each cell is approximately $8.1 \mathrm{~mm}$. This concentration is somewhat above the range generally reported for cholinergic neurons, 0.3-3.0 mM (McCaman, 1984). If additional cholinergic neurons with processes in the medullary neuropile (e.g., centrifugal neurons) are discovered, then the above estimates will have to be adjusted downward.

Although there are numerous differences between crustacean and insect optic lobes, there are enough common architectural features to justify a comparison of our cytochemical findings and related results in diptera. As noted above, there is a general similarity in the overall distribution of $\Lambda \mathrm{Ch}$ in crayfish and fly optic lobe. In Drosophila (Buchner et al., 1986; Gorczyca and Hall, 1987), the antibody to choline acetyltransferase (ChAT) produces a tangentially stratified binding pattern in the second and third optic neuromeres (medulla and lobula). Furthermore, there is a clear indication of a columnar organization in the reactive elements. Although the cell types were not identified, it is well established (Strausfeld and Nassel, 1980) that the transmedullary monopolar cells constitute the most numerous cell class in the dipteran medullary columns. Furthermore, the fly lamina exhibits ChAT antibody reactivity in the terminals of putative centrifugal neurons that may be analogous to the $\mathrm{ACh}$ like reactive terminals in crayfish lamina. Thus, there is considerable similarity in the anatomical distribution of ACh-like reactivity in crayfish and ChAT-like reactivity in Drosophila.

Additionally, ACh receptors have been localized in Drosophila medulla and lobula with radiolabeled alpha-bungarotoxin (Schmidt-Nielsen et al., 1977). The putative receptors exhibit a tangentially stratified distribution in the medulla and anterior and posterior lobula. The autoradiographs are not inconsistent with toxin binding to tangentially arrayed dendritic arbors of multicolumnar neurons. A similar binding pattern is reported for alpha-bungarotoxin in the moth medulla (Maxwell and Hildebrand, 1981). Unfortunately, it is no longer clear that the toxin specifically binds to physiologically active $\mathrm{ACh}$ receptors in all invertebrate neural tissue (McCaman, 1984).

It is useful to consider our results in the context of the other transmitters localized in the crayfish optic lobe. The medulla externa contains catecholamines (probably dopamine) (Elofsson and Klemm, 1972; Elofsson et al., 1977), serotonin (Elofsson, 1983), and proctolin (Siwicki and Bishop, 1986). Each transmitter is distributed in several tangential bands: 3 for dopamine and serotonin and 2 for proctolin. Serotonin and dopamine are contained in somata of the medullary cell body area, and proctolin is found in a unique ventromedial, longitudinal cell body cluster. The distal catecholamine-containing band is presumably associated with the terminals of centripetal, columnar T-neurons. The neurons responsible for the other transmitter bands are unknown. In crayfish lamina ganglionaris, dopamine is tentatively assigned to amacrine neurons (Strausfeld and Nassel, 1980). The spatial distribution of ACh overlaps but differs from that of any of the other histochemically mapped transmitters.

The functional significance of the above transmitters to vision or synaptic activity in the optic lobe is unknown. In the companion paper (Pfeiffer and Glantz, 1989), we show that ACh plays diverse roles in synaptic transmission to several classes of visual interneurons.

\section{References}

Barker, D. L., E. Herbert, J. G. Hildebrand, and E. A. Kravitz (1972) Acetylcholine and lobster sensory neurones. J. Physiol. (Lond.) 226. 205-229.

Beltz, B. S., and E. A. Kravitz (1983) Mapping of serotonin-like immunoreactivity in the lobster nervous system. J. Neurosci. 3: 583602.

Buchner, E., S. Buchner, G. Crawford, W. T. Mason, P. M. Salvaterra, and D. B. Sattelle (1986) Choline acetyltransferase-like immunoreactivity in the brain of Drosophila melanogaster. Cell Tissue Res. 246: 57-62.

Campos-Ortega, J. A. (1974) Autoradiographic localization of ${ }^{3} \mathrm{H}-$ gamma-aminobutyric acid uptake in the lamina ganglionaris of Musca and Drosophila. Z. Zellforsch. 147: 415-431.

Datum, K. H., R. Weiler, and F. Zettler (1986) Immunocytochemical demonstration of gamma-aminobutyric acid and glutamic acid decarboxylase in $\mathrm{R} 7$ photoreceptors and $\mathrm{C} 2$ centrifugal fibers in the blowfly visual system. J. Comp. Physiol. 159: 241-249.

Elias, M. S., and P. A. Evans (1983) Histamine in the insect nervous system: Distribution synthesis and metabolism. J. Neurochem. 41: 562-568.

Elias, M. S., and P. A. Evans (1984) Autoradiographic localization of ${ }^{3} \mathrm{H}$-histamine accumulation by the visual system of the locust. Cell Tissue Res. 238: 105-112. 
Elofsson, R. (1983) 5-HT immunoreactivity in the central nervous system of the crayfish. Cell Tissue Res. 232: 221-236.

Elofsson, R., and N. Klemm (1972) Monamine containing neurons in the optic ganglia of crustaceans and insects. Z. Zellforsch. Mikrosk. Anat. 133: $475-479$.

Elofsson, R., D. R. Nassel, and H. Myhrberg (1977) A catecholaminergic neuron connecting the first two optic neuropiles (lamina ganglionaris and medulla externa) of the crayfish Pacifastacus leniusculus. Cell Tissue Res. 182: 287-297.

Elofsson, R., L. Laxmyr, E. Rosengren, and C. Hansson (1982) Identification and quantitative measurements of biogenic amines and dopa in the central nervous system and haemolymph of the crayfish, $\mathrm{Pa}$ cifastacus leniusculus. Comp. Biochem. Physiol. 71C: 195-201.

Garcia, U., and H. Arechiga (1986) GABAergic input to crustacean neurosecretory cells. Soc. Neurosci. Abstr. 12: 243.

Geffard, M., A. McRae-Dequerce, and M. L. Sovan (1985) Immunocytochemical detection of acetylcholine in the rat central nervous system. Science 229: 77-79.

Gorczyca, M. H., and J. C. Hall (1987) Immunohistochemical localization of choline acetyltransferase during development and in cha mutants of drosophila melanogaster. J. Neurosci. 7: 1361-1369.

Hildebrand, J. G., J. G. Townsel, and E. A. Kravitz (1974) Distribution of acetylcholine, choline, choline acetyltransferase and acetylcholinesterase in regions and single identified axons of the lobster nervous system. J. Neurochem. 23: 951-963.

Homberg, U., T. G. Kingan, and J. G. Hildebrand (1987) Immunocytochemistry of GABA in the brain and subesophegeal ganglion of Manduca Sexta. Cell Tissue Res. 248: 1-24.

Ikuta, S., I. Shigeyuki, H. Misaki, and Y. Horiuti (1977) Purification and characterization of choline oxidase from Arthrobacter globiformis. J. Biochem. 82: 1741-1749.

Israel, M., and B. Lesbats (1981) Continuous determination by a chemiluminescent method of acetylcholine release and compartmentation in Torpedo electric organ synaptosomes. J. Neurochem. 37: $1475-1483$.

Israel, M., and B. Lesbats (1987) The use of bioluminescence techniques in neurobiology, with emphasis on the cholinergic system. In Neurochemistry: A Practical Approach, A. J. Turner and H. S. Bachelard, eds., pp. 113-135, IRL, Oxford, UK.

Kirk, M. D. (1982) The Crayfish Visual System. Intracellular Studies and Morphologies of Identical Neurons. Ph.D. dissertation, Rice University.

Kirk, M. D., B. Waldrop, and R. M. Glantz (1982) The crayfish sustaining fibers. I. Morphological representation of visual receptive fields in second optic neuropil. J. Comp. Physiol. 146: 175-179.

Kirk, M. D., B. Waldrop, and R. M. Glantz (1983) A quantitative correlation of contour sensitivity with dendritic density in an identified visual interneuron. Brain Res. 274: 231-237.

Mancillas, J. R., J. F. McGinty, A. I. Selverston, H. Karten, and F. E. Bloom (1981) Immunocytochemical localization of enkephalin and substance-P in retina and eyestalk neurons of lobster. Nature 293: 576-578.

Maxwell, G. D., and J. G. Hildebrand (1981) Anatomical and neurochemical consequences of deafferentation in the development of the visual system of the moth Manduca Sexta. J. Comp. Neurol. 195: $667-680$.

Maxwell, G. D., I. F. Tait, and I. G. Hildebrand (1978) Regional synthesis of neurotransmitter candidates in the central nervous system of the moth Manduca Sexta. Comp. Biochem. Physiol. 61c: 109119.

McCaman, M. W. (1984) Neurochemistry of invertebrates. In Handbook of Neurochemistry, Vol. 7, A. Lajtha, ed., pp. 613-700, Plenum, New York.

Meyer, E. P., C. Matute, P. Streit, and D. R. Nassel (1986) Insect optic lobe neurons identifiable with monoclonal antibodies to GABA. Histochemistry $84: 207-216$.

Nassel, D. R., and T. H. Waterman (1977) Golgi EM evidence for visual information channeling in the crayfish lamina ganglionaris. Brain Res. 130: 556-564.

Nassel, D. R., E. R. Meyer, and N. Klemm (1985) Mapping and ultrastructure of serotonin-immunoreactive neurons in the optic lobes of three insect species. I. Comp. Neurol. 232: 190-204.

Ohnishi, S. T., and J. K. Barr (1978) A simplified method for quantitating protein using the biuret and phenol reagents. Anal. Biochem. 86: $193-200$

Pfeiffer, C., and R. M. Glantz (1989) Cholinergic synapses and the organization of contrast detection in the crayfish optic lobe. J. Neurosci. 9: 1872-1882.

Schmidt-Nielsen, B. K., J. I. Gepner, N. N: H. Teng, and L. M. Hall (1977) Characterization of an $\alpha$-bungarotoxin binding component from Drosophila melanogaster. J. Neurochem. 29: 1013-1029.

Schueler, P. A., A. J. Madsen, W. S. Herman, and R. Elder (1986) Immunohistochemical mapping of distal retinal pigmeht hormone in the crayfish central nervous system. Soc. Neurosci. Abstr. 12: 242.

Siwicki, K. S., and C. A. Bishop (1986) Mapping of proctolin-like immunoreactivity in the nervous system of lobster and crayfish. J. Comp. Neurol. 243: 435-453.

Strausfeld, N. J., and D. R. Nassel (1980) Neuroarchitecture of brain regions that subserve the compound eyes of crustacea and insects. In Handbook of Sensory Physiology, Vol. 8, Pt. 6B, pp. 1-132, SpringerVerlag, New York.

Vieillemaringe, J., P. Duris, M. Geffard, M. LeMoal, M. Deladge, C. Bensch, and J. Girardie (1984) Immunohistochemical localization of dopamine in the brain of the insect Locusta migratoria in comparison with the catecholamine distribution determined by histofluorescence technique. Cell Tissue Res. 237: 391-394.

Waldrop, B., and R. M. Glantz (1985a) Synaptic mechanisms of a tonic EPSP in crustacean visual interneurons: Analysis and simulation. J. Neurophysiol. 54: 636-650.

Waldrop, B., and R. M. Glantz (1985h) Nonspiking local interneurons mediate surround inhibition in crayfish sustaining fibers. J. Comp. Physiol. 156: 763-774.

Wang-Bennett, L. T., and R. M. Glantz (1986) Immunocytochemical visualization of acetylcholine and glutamate in the brain and eyestalk of crayfish. Soc. Neurosci. Abstr. 12: 243.

Wang-Bennett, L. T., and R. M. Glante (1987a) The functional organization of the crayfish lamina ganglionaris. I. Nonspiking monopolar cells. J. Comp. Physiol. 161: 131-145.

Wang-Bennett, L. T., and R. M. Glantz (1987b) The functional organization of the crayfish lamina ganglionaris. II. Large field spiking and nonspiking cells. J. Comp. Physiol. 161: 147-160.

Wang-Bennett, L. T., M.-L. Sovan, and R. M. Glantz (1988) Immunocytochemical studies of the distribution of acetylcholine in the crayfish brain. J. Comp. Neurol. 27.3: 330-343 